\title{
PENGEMBANGAN BUKU TEKS TEMATIK TEMA PERMAINAN UNTUK KELAS III SDN TRIDADI SLEMAN YOGYAKARTA
}

\section{DEVELOPMENT OF A THEMATIC TEXTBOOK FOCUSING ON THEME OF GAME FOR GRADE III STUDENTS OF ELEMENTARY SCHOOL OF TRIDADI SLEMAN YOGYAKARTA}

\author{
Yohannes Kurniawan Barus, Djukri \\ PPs UNY, Universitas Negeri Yogyakarta \\ annezbarus@yahoo.com,pps@uny.ac.id
}

\begin{abstract}
Abstrak
Penelitian ini bertujuan untuk menghasilkan buku teks tematik "tema Permainan". Penelitian ini merupakan Research and Development (R\&D). Pengembangan dilakukan dengan mengacu pada model pengembangan 4-D yang meliputi tahap Define, Design, Develop, dan Dissemination. Subjek pada penelitian ini adalah siswa kelas III SD Negeri Tridadi yang berjumlah 28 orang. Hasil penelitian menunjukkan sebagai berikut: (1) Penilaian dari ahli materi dan media terhadap buku teks tematik tema permainan ditinjau dari aspek kelayakan isi berkategori "sangat baik", aspek penyajian berkategori "Sangat Baik", aspek kebahasaan berkategori "Sangat Baik", dan aspek kegrafikan berkategori "Sangat Baik". Penilaian dari guru aspek kelayakan isi berkategori "Baik", aspek penyajian "Sangat Baik", aspek kebahasaan berkategori "Baik", dan aspek kegrafikan berkategori "Baik". (2) Respon siswa terhadap buku teks yang dikembangkan menunjukkan respons yang "Baik", (3) Efektivitas buku teks tematik yang dikembangkan termasuk dalam kategori "Tinggi”, ditunjukkan dari rerata skor gain seluruh siswa kelas III dalam uji coba terbatas dan diperluas sebesar 0,71.
\end{abstract}

Kata kunci: pengembangan, buku teks tematik, tema permainan

\begin{abstract}
This research aims to develop a thematic textbook focusing on "theme of game". This research is categorized as a Research and Development study. Research design was adopted from the 4-D model through Define, Design, Develop and Dissemination. Subjects in this research were third grade student's of Tridadi elementary school 28 in total. The results show as follows: (1) The assessment of materials and media experts on the thematic textbook focusing on "theme of game" in terms of contents aspects are "very good", presentation aspects are "very good", aspects of language are "very good", and graphical aspects are "very good". On the contents aspects of the assessment of teachers is categorized "good", the presentation aspect is "very good", aspects of language is "good", and graphical aspects is "good". (2) Student's response to the textbooks developed is considered is "good", (3) The effectiveness of the thematic textbooks show "high" category which was shown from the average score of all students in grade III gain by 0.71 .
\end{abstract}

Keywords: development, thematic textbook, theme of game 


\section{Pendahuluan}

Berbagai inovasi telah banyak dilakukan pemerintah untuk meningkatkan kualitas pembelajaran di sekolah terutama pada tingkat Sekolah Dasar. Hal itu dilakukan karena saat ini masih banyak target pembelajaran yang belum tercapai secara maksimal. Salah satu inovasi pembelajaran yang dilakukan pemerintah adalah diterapkannya model pembelajaran tematik, yaitu model pembelajaran terpadu yang dikhususkan kepada siswa kelas 1 sampai 3 Sekolah Dasar.

Pembelajaran tematik merupakan strategi pembelajaran yang diterapkan bagi anak kelas awal sekolah dasar. Sesuai dengan tahapan perkembangan anak, karakteristik cara anak belajar, konsep belajar dan pembelajaran bermakna, maka kegiatan pembelajaran bagi anak kelas awal SD sebaiknya dilakukan dengan pembelajaran tematik. Pembelajaran tematik adalah pembelajaran terpadu yang menggunakan tema untuk mengaitkan beberapa mata pelajaran sehingga dapat memberikan pengalaman bermakna kepada siswa. Tema adalah pokok pikiran atau gagasan pokok yang menjadi pokok pembicaraan dalam proses pembelajaran.

Dalam pembelajaran tematik guru perlu mengemas atau merancang pengalaman belajar yang akan mempengaruhi kebermaknaan belajar siswa. Pengalaman belajar yang menunjukkan kaitan unsur-unsur konseptual menjadikan proses pembelajaran lebih efektif. Kaitan konseptual antarmata pelajaran yang dipelajari akan membentuk skema, sehingga siswa akan memperoleh keutuhan dan kebulatan pengetahuan. Selain itu, dengan penerapan pembelajaran tematik di sekolah dasar akan sangat membantu siswa, karena sesuai dengan tahap perkembangannya siswa yang masih melihat segala sesuatu sebagai satu keutuhan. Model pembelajaran ini pada hakikatnya merupakan suatu pendekatan pembelajaran yang memungkinkan peserta didik baik secara individual maupun kelompok aktif mencari, menggali, dan menemukan konsep serta prinsip secara holistik dan otentik. Hal tersebut senada dengan pendapat Peters (1995, p.1) "The thematic approach, on the other hand, encourages holistic study of a subject."

Dalam proses belajar mengajar di sekolah, buku teks juga berperan sebagai referensi materi pembelajaran bagi guru dan siswa. Peserta didik membutuhkan referensi atau acuan untuk menggali ilmu agar pemahaman peserta didik lebih luas dan tidak sebatas men- cermati materi yang diterangkan oleh guru sehingga kemampuannya dapat lebih dioptimalkan. Buku teks pelajaran dipakai sebagai salah satu sumber belajar yang utama dalam proses belajar dan membelajarkan di sekolah (Sitepu 2012, p.5). UNESCO (2005, p.i) mendefinisikan textbook sebagai: "The core learning medium composed of text and or images designed to bring about a specific set of educational outcomes; traditionally a printed and bound book including illustrations and instructions for facilitating sequences of learning activities." Pengertian di atas dapat diartikan sebagai berikut: media pembelajaran inti yang terdiri dari teks atau gambar yang dirancang untuk mencapai kompetensi dasar siswa, secara tradisional sebuah buku dicetak dan di dalamnya terdapat ilustrasi dan petunjuk untuk memfasilitasi serangkaian kegiatan belajar. Implikasi dari definisi tersebut adalah buku teks tematik ini merupakan media pembelajaran yang menyediakan materi-materi dari berbagai mata pelajaran yang dikaitkan dengan tema permainan yang di dalamnya terdapat kegiatan-kegiatan yang bertujuan untuk mencapai kompetensi dasar siswa.

Buku teks menuntun peserta didik untuk berlatih, praktek, atau mencoba teori-teori yang sudah dipelajari dari buku teks tersebut. Oleh karena itu, guru harus cerdas dalam menentukan buku teks yang akan digunakan di dalam pembelajaran karena buku teks sangat berpengaruh dalam proses pembelajaran. Pentingnya informasi yang disediakan oleh buku teks, menjadikan keberadaannya menjadi sangat penting. Hal ini sebagaimana dituturkan oleh Quest (2006, p.5): "The textbook hold a central place in school works because its offer a compact arrangement of educational material." Implikasi dari pernyataan tersebut adalah bahwa buku teks merupakan bahan ajar yang sangat penting di sekolah atau dalam proses pembelajaran karena buku teks berisi materimateri pelajaran yang akan diajarkan kepada siswa.

Fungsi buku teks bagi guru adalah sebagai pedoman untuk mengidentifikasi apa yang harus diajarkan atau dipelajari oleh siswa, mengetahui urutan penyajian bahan ajar, mengetahui teknik dan metode pengajarannya, memperoleh bahan ajar secara mudah, dan menggunakannya sebagai alat pembelajaran siswa di dalam atau di luar sekolah. Sedangkan fungsi buku teks bagi siswa adalah sebagai sarana kepastian tentang apa yang ia pelajari, alat kontrol untuk mengetahui seberapa banyak 
dan seberapa jauh ia telah menguasai materi pelajaran, alat belajar (di luar kelas buku teks berfungsi sebagai guru) di mana ia dapat menemukan petunjuk, teori, maupun konsep dan bahan-bahan latihan atau evaluasi.

Buku teks berkaitan erat dengan kurikulum yang sedang berlaku, oleh karena itu buku teks yang baik harus relevan dan menunjang pelaksanaan kurikulum. Dalam kerangka dasar dan struktur kurikulum, khusus mengenai struktur kurikulum SD/MI, salah satunya ditentukan bahwa pembelajaran pada kelas I sampai III dilaksanakan melalui pendekatan tematik, sedangkan pada kelas IV sampai dengan VI dilaksanakan melalui pendekatan mata pelajaran (BNSP dalam Indrawati, 2009, pp.12). Dalam konteks pengembangan buku teks pada penelitian ini kurikulum yang digunakan sebagai acuan pengembangan adalah Kurikulum Tingkat Satuan Pendidikan (KTSP) karena di sekolah tersebut masih menggunakan kurikulum KTSP dan belum diterapkannya Kurikulum 2013.

Kondisi yang terjadi saat ini adalah buku pelajaran kelas rendah masih terpisah-pisah antar pelajaran, sehingga pembelajaran yang terjadi sering tidak sesuai dengan tema yang telah ditetapkan oleh guru yang mengacu pada silabus BSNP. Karena kegiatan pembelajaran di kelas rendah yang terpisah pisah untuk setiap mata pelajaran akan menyebabkan kurang berkembangnya kemampuan anak untuk berpikir holistik. Di samping itu juga guru masih sulit meninggalkan kebiasaan kegiatan pembelajaran yang penyajiannya masih berdasarkan bidang studi atau mata pelajaran, karena memang buku teks pelajaran yang digunakan oleh guru saat ini masih per mata pelajaran. Selain itu guru juga belum mengembangkan bahan ajar sendiri yang dapat memadukan beberapa mata pelajaran menjadi satu tema. Fenomena yang sering terjadi akhir akhir ini banyak buku sekolah yang tidak sesuai dengan Standar Isi yang telah ditetapkan bahkan ada buku pelajaran yang memuat kata-kata dan gambar gambar yang tidak layak dibaca atau dilihat oleh siswa sekolah dasar, hal ini tentu sangat tidak baik terhadap perkembangan siswa. Berdasarkan pengamatan peneliti di SD Negeri Tridadi Sleman dalam pembelajaran kelas rendah terutama kelas 3 masih menggunakan buku teks pelajaran yang terpisah-pisah yang tidak terkait dengan tema tertentu, oleh karena itu perlu dikembangkan buku teks tematik yang sesuai dengan karakteristik siswa dan kondisi di SD Negeri Tridadi.
Kondisi yang terjadi di lapangan juga menunjukkan bahwa guru kelas 3 masih merasa kesulitan untuk melakukan pembelajaran tematik karena bahan ajar yang belum mendukung. Hal tersebut terlihat dari masih kesulitan guru dalam mengaitkan materi dengan tema ditambah lagi dengan buku pelajaran yang terpisah-pisah sehingga guru sering kali lupa mengaitkan materi dengan tema yang telah ditentukan sebelumnya. Kebutuhan guru dengan adanya bahan ajar yang inovatif yang sesuai dengan pembelajaran tematik juga mutlak diperlukan untuk meningkatkan kualitas pembelajaran khususnya pembelajaran tematik. Dengan adanya bahan ajar yang mendukung proses pembelajaran maka kegiatan pembelajaran yang berlangsung akan menjadi efektif dan efisien untuk itu diperlukan sebuah bahan ajar khusus tematik dalam proses pembelajaran di kelas III terutama Sekolah Dasar Negeri Triadi Sleman Yogyakarta.

Dalam pembelajaran tematik buku teks pelajaran sebaiknya dibuat berdasarkan te-matema tertentu. Mengingat pembelajaran di kelas rendah menggunakan pendekatan tematik, seharusnya buku teks pelajaran kelas rendah harus dibuat berdasarkan tema dari silabus yang telah dibuat oleh BSNP, sehingga materi yang disajikan menjadi suatu kesatuan utuh dan tidak terpisah-pisah agar setiap materi yang telah dipadukan oleh suatu tema dapat terintegrasi dengan baik. Hal ini juga akan memudahkan guru dalam mengaitkan setiap mata pelajaran dengan tema tersebut, sehingga setiap pelajaran atau materi yang disampaikan tidak terlepas dari tema yang telah ditentukan.

Permainan merupakan tema yang sangat baik untuk dijadikan tema dalam pembelajaran tematik, karena permainan sangat lekat dengan dunia anak-anak terutama kelas III SD. Miller (2008, pp.3-4) menyatakan pentingnya permainan sebagai berikut: Outside the classroom, playing is one of the fundamental human activities, one of the first that human children develop together with talking, toddling, and relating to others.

Pentingnya bahan ajar khusus tematik juga dinyatakan Rusman (2012, pp.282-283): "Penerapan model pembelajaran tematik di sekolah dasar menuntut tersedianya bahan ajar, terutama buku ajar yang memadai dan dapat memenuhi kebutuhan pembelajaran yang terintegrasi antar satu mata pelajaran dengan mata pelajaran lainnya bahkan dengan kehidupan. Sekalipun buku ajar yang sudah ada saat ini 
untuk masing-masing mata pelajaran masih dapat dipergunakan dalam pelaksanaan pembelajaran tematik, namun pada masa mendatang perlu diupayakan adanya buku suplemen khusus yang memuat bahan ajar yang terintegrasi untuk membantu siswa sejak dini memahami berbagai ilmu pengetahuan secara interdisipliner. Bahan ajar tersebut berpangkal dari tematema yang melekat dalam kehidupan siswa dan lingkungannya."

Diharapkan dengan adanya buku teks yang dibuat berdasarkan tema yang sesuai dengan pembelajaran tematik, maka proses pembelajaran tematik yang sebenarnya dapat diimplementasikan dengan baik oleh guru sehingga nilai-nilai yang terdapat dalam pembelajaran tematik dapat dirasakan oleh siswa. Oleh sebab itu penelitian pengembangan ini bertujuan untuk menghasilkan buku teks tematik tema permainan yang layak bagi siswa kelas III SDN Tridadi Sleman Yogyakarta, dan untuk mengetahui respons siswa terhadap buku teks tematik tema permainan yang dikembangkan, serta untuk mengetahui efektivitas buku teks tematik tema permainan yang dikembangkan dalam proses pembelajaran dilihat dari peningkatan hasil belajar siswa di kelas III SDN Tridadi Sleman Yogyakarta.

\section{Metode}

Jenis Penelitian dan Model Pengembangan

Jenis penelitian dalam penelitian ini adalah Research and Development atau penelitian pengembangan. Borg \& Gall (1983, p.772) memberikan definisi penelitian pengembangan pendidikan sebagai berikut: "Educational Research and development is a process used to develop and validate educational products". Penelitian pengembangan merupakan suatu usaha untuk mengembangkan sebuah produk atau material lainnya dalam proses pembelajaran untuk digunakan disekolah dalam proses pembelajaran dikelas. Dalam proses pengembangan tersebut terdapat tahapan-tahapan atau langkahlangkah yang harus dilakukan peneliti sesuai dengan model pengembangan yang digunakan dalam suatu proses penelitian pengembangan. Model yang digunakan dalam penelitian ini mengacu pada pengembangan model 4-D (Four-D Models) yang diperkenalkan oleh Thiagarajan Semmel dan Semmel (1974). Tahapan pengembangan tersebut adalah: (a) Tahapan Pendahuluan (define), (b) Tahapan Pe- rencanaan (design), (c) Tahapan Pengembangan (develop), (d) Tahapan desiminasi (desiminate).

\section{Waktu dan Tempat Penelitian}

Penelitian ini dimulai pada bulan Maret sampai dengan Juni tahun 2013. Penelitian dilakukan di Sekolah Dasar Negeri Tridadi Sleman Yogyakarta. Penelitian dimulai dengan mengembangkan produk terlebih dahulu dan kemudian diujicobakan di sekolah yang telah disebutkan di atas.

\section{Subjek Penelitian}

Setelah produk hasil pengembangan divaliadasi oleh ahli materi dan ahli media dan dinyatakan layak, maka selanjutnya produk hasil pengembangan tersebut diujicobakan kepada subjek uji coba (siswa). Subjek uji coba dalam penelitian pengembangan ini adalah siswa kelas 3 (kelas non pararel) Sekolah Dasar Negeri Tridadi Sleman Yogyakarta yang berjumlah 28 orang siswa.

\section{Prosedur Pengembangan}

Prosedur pengembangan dalam penelitian ini diadaptasi dari model pengembangan menurut Thiagarajan, Semmel \& Semmel yang dikenal sebagai model 4-D. Pengembangan buku teks tematik tema permainan yang dilakukan dalam penelitian ini meliputi empat tahap yaitu tahap define (pendefinisian), tahap design (perancangan), tahap develop, (pengembangan), dan tahap disseminate (penyebaran). Berikut penjelasan dari masing-masing tahap dalam penelitian pengembangan ini :

\section{Tahap Define (Pendefinisian)}

Tujuan dalam tahap ini adalah untuk menetapkan dan mendefinisikan syarat-syarat dalam proses pembelajaran. Tahap ini meliputi lima langkah pokok yaitu : Analisis awal-akhir atau analisis kebutuhan bertujuan untuk memunculkan dan menetapkan masalah dasar yang dihadapi dalam pembelajaran tematik di sekolah dasar kelas 3 sehingga dibutuhkan pengembangan buku teks tematik tema permainan. Analisis siswa merupakan telaah karakteristik siswa yang meliputi tingkat perkembangan kognitif, kemampuan awal siswa, dan latar belakang sosial budaya termasuk mengidentifikasi jenis-jenis permainan yang sudah akrab dengan kehidupan sehari-hari siswa. Analisis tugas mencakup pendalaman terhadap materi dan indikator pencapaian hasil belajar. Analisis konsep merupakan identifikasi konsep-konsep 
utama yang akan diajarkan dan menyusunnya secara sistematis serta mengaitkan satu konsep dengan konsep lainnya yang relevan. Hasil analisis tugas dan analisis konsep digunakan sebagai acuan untuk merumuskan tujuan pembelajaran yang dinyatakan dengan tingkah laku sebagai penjabaran dari standar kompetensi dan kompetensi dasar.

\section{Tahap Design (Perancangan)}

Tahap perancangan dimulai dengan menyusun soal tes acuan patokan dalam hal ini berupa soal pretest dan posttest. Soal pretest dan posttest digunakan untuk mengetahui kemampuan awal dan hasil akhir belajar siswa. Soal pretest dan posttest tersebut akan dijadikan alat ukur untuk melihat efektivitas produk yang dikembangkan dalam proses pembelajaran dilihat dari peningkatan tes awal sebelum pembelajaran dengan produk yang dikembangkan dan tes sesudah pembelajaran menggunakan produk yang dikembangkan. Dalam perancangan ini juga dibuat soal-soal latihan yang akan dikerjakan siswa selama melakukan pembelajaran dengan buku teks yang dikembangkan.

Langkah selanjutnya adalah menentukan media pembelajaran yang akan digunakan dalam proses pembelajaran dengan menggunakan buku teks tematik tema permainan. Dalam pemilihan media juga dilakukan pemilihan bahan-bahan yang akan digunakan oleh siswa dalam melakukan kegiatan atau percobaan. Pemilihan media pembelajaran dan bahan untuk kegiatan ini dilakukan dengan mempertimbangkan ketersediaan dan keterjangkauan siswa dalam menyiapkan alat dan bahan. Langkah berikut adalah mulai membuat layout atau rancangan awal buku teks tematik tema permainan, mulai dari mengumpulkan gambar-gambar penunjang, mendesain cover atau sampul buku, dan mendesain tampilan dalam buku.

\section{Tahap Development (Pengembangan)}

Sebelum dilaksanakan uji coba untuk mengetahui kelayakan produk dari sisi materi dan media perlu mendapatkan validasi dari ahli materi dan ahli media. Validasi materi dilakukan oleh dosen Program Studi Pendidikan Dasar Program Pascasarjana Universitas Negeri Yogyakarta dosen yang terlibat dalam validasi ini adalah Dr. Muhammad Nurwangid, sedangkan validasi media dilakukan oleh dosen Program Studi Teknologi Pembelajaran Program Pascasarjana Universitas Negeri Yogyakarta adalah Prof. Dr. C. Asri Budiningsih. Masingmasing dosen ahli tersebut memberikan validasi terhadap produk secara terstruktur dengan memberikan data kualitatif berupa lembar validasi dan tidak terstruktur berupa catatan dan komentar serta masukan-masukan secara lisan pada saat konsultasi validasi.

Hasil validasi ahli materi dan ahli media sebagai dasar dilakukannya uji coba produk. Hasil dalam tahap pengembangan ini meliputi hasil validasi ahli materi dan ahli media serta uji coba terbatas. Validasi ahli terhadap produk yang dikembangkan adalah untuk menggali komentar saran baik secara tertulis maupun lisan dengan cara melakukan diskusi tentang produk yang dikembangkan. Pada tahap ini dilaksanakan dengan menyerahkan produk tang dikembangkan untuk dinilai dengan instrumen penilaian materi maupun penilaian media. Validasi juga dimaksudkan untuk mengetahui aspek kebenaran dan kelayakan baik dari segi atau sisi materi dan media. Validasi dari ahli materi dan ahli media tersebut digunakan untuk mengetahui kualitas produk yang dikembangkan.

Setelah evaluasi dari ahli materi dan media yang telah dilakukan, penilaian, masukan, saran, dan komentar dari para ahli dijadikan pedoman untuk merevisi produk awal buku teks tematik tema permainan. Setelah produk awal dinyatakan valid kemudian produk yang telah dikembangkan siap untuk digunakan dalam uji coba terbatas. Uji coba terbatas dilakukan di SD Negeri Tridadi Sleman Yogyakarta kelas 3 yang terdiri dari 9 orang siswa. Dari kesembilan orang siswa tersebut dipilih 3 orang yang mewakili tingkat prestasi tinggi, 3 orang dengan tingkat prestasi sedang, dan 3 orang dengan tingkat prestasi rendah, penentuan ini berdasarkan rangking pada semester 1. Dalam uji coba terbatas ini siswa diberikan kesempatan untuk membaca dan mempelajari produk buku yang dikembangkan. Uji coba terbatas ini bertujuan untuk melihat apakah terdapat kelemahan-kelemahan yang terdapat dalam buku teks tematik tema permainan. Setelah uji coba terbatas kemudian produk direvisi kembali berdasarkan kelemahan-kelemahan yang ditemukan pada saat uji coba terbatas.

\section{Tahap Diseminasi (Penyebaran)}

Pada tahap penyebaran ini dilakukan uji coba lapangan yaitu melakukan proses pembelajaran tematik di kelas 3 dengan menggunakan produk yang dikembangkan yaitu buku teks tematik tema permainan. Uji coba lapangan 
ini dimaksudkan untuk memperoleh respons, umpan balik terhadap bahan ajar yang telah dikembangkan dan juga melihat efektivitas produk dilihat dari peningkatan skor hasil pretest dan skor hasil posttest. Apabila respons sasaran pengguna bahan ajar sudah baik maka produk akhir dari penelitian pengembangan ini dapat digunakan dalam proses pembelajaran tematik di kelas 3 Sekolah Dasar.

Uji lapangan ini dilakukan di kelas 3 SDN Tridadi yang terdiri dari 28 orang siswa. Uji coba lapangan atau diperluas ini berlangsung selama 9 kali pertemuan, selama kurun waktu tersebut siswa dan guru menggunakan produk buku teks tematik tema permainan sebagai bahan ajar dalam proses pembelajaran tematik di kelas. Sebelum produk buku teks tematik digunakan dalam proses pembelajaran terlebih dahulu siswa diberikan soal pretest untuk melihat kemampuan awal siswa sebelum menggunakan produk. Setelah melakukan proses pembelajaran dengan menggunakan produk yang dikembangkan kemudian siswa diberikan soal posttest untuk melihat sejauh mana pemahaman materi dapat dikuasai oleh siswa.

Hasil dari perhitungan pretest dan posttest inilah yang akan menentukan efektivitas produk buku teks tematik yang dikembangkan. Apabila skor nilai gain menunjukkan kategori tinggi maka produk buku teks tematik yang dikembangkan dikatakan efektif. Sehingga produk akhir dari proses pengembangan buku teks tematik tema permainan ini sudah dapat digunakan sebagai salah satu bahan ajar pembelajaran tematik di kelas 3 .

\section{Jenis Data dan Instrumen Pengumpulan Data}

Data yang akan diperoleh dalam penelitian ini berupa data kualitatif dan data kuantitatif. Data kualitatif diperoleh dari komentar dan tanggapan siswa, guru, ahli materi dan ahli media. Data kuantatif diperoleh dari hasil pengisian lembar validasi ahli media, ahli materi, guru dan respons peserta didik serta data haul belajar siswa dari soal pretest dan posttest. Data kuantatif akan diubah menjadi data kualitatif yang dapat dengan jelas memberikan gambaran kualitas produk yang dikembangkan yaitu buku teks tematik tema permainan. Instrumen yang digunakan untuk mengumpulkan data pada penelitian pengembangan ini berupa lembar validasi ahli materi dan ahli media, lembar respons siswa, lembar penilaian guru dan soal tes. Instrumen yang dimaksudkan tersebut digunakan untuk mengevaluasi kualitas produk buku teks tematik tema permainan dan instrumen berupa soal pretest dan posttest untuk mengetahui efektivitas buku teks tematik tema permainan dilihat dari peningkatan hasil belajar siswa dalam proses pembelajaran tematik dengan menggunakan produk yang telah dikembangkan.

\section{Teknik Analisis Data}

Data yang diperoleh melalui kegiatan uji coba diklasifikasikan menjadi 2, yaitu data kualitatif dan data kuantitatif. Data kualitatif dalam penelitian ini berupa kritik dan saran yang dikemukakan ahli materi, ahli media, dan guru. Data-data ini dihimpun dan disarikan untuk memperbaiki produk buku teks tematik yang dikembangkan. Sedangkan data kuantitatif berupa skor pada masing-masing butir instrumen yang telah diisi oleh ahli materi, ahli media dan subjek coba, serta data pretest dan posttest pada pelaksanaan uji coba terbatas dan diperluas.

\section{Analisis Kelayakan atau Hasil Validasi ahli}

Teknik yang digunakan untuk memberikan kriteria nilai kualitas produk yang dikembangkan yaitu: Pertama, data yang diperoleh dari angket diubah dulu menjadi data interval seperti tersaji pada Tabel 1 berikut :

Tabel 1. Kriteria Penskoran Item Pada Angket

\begin{tabular}{cc}
\hline Kriteria & Skor \\
\hline Sangat Baik & 5 \\
Baik & 4 \\
Cukup Baik & 3 \\
Kurang Baik & 2 \\
Sangat Kurang Baik & 1 \\
\hline
\end{tabular}

Kedua, skor yang diperoleh kemudian dijumlahkan dan dirata-ratakan, selanjutnya dikonversikan menjadi nilai pada skala 5, dengan acuan tabel yang diadaptasi dari Sukardjo (2010, pp.100-101) seperti tersaji pada Tabel 2 di bawah ini :

Tabel 2. Konversi Skor menjadi Kriteria pada Skala Lima

\begin{tabular}{ccc}
\hline Nilai & Interval Skor & Kriteria \\
\hline $\mathrm{A}$ & $\mathrm{X}>\overline{\mathrm{X}}_{\mathrm{i}}+1,80 \mathrm{SB}_{\mathrm{i}}$ & Sangat \\
$\mathrm{B}$ & $\bar{X}_{\mathrm{i}}+0,60 \mathrm{SB}_{\mathrm{i}}<\mathrm{X} \leq \bar{X}_{\mathrm{i}}+1,80 \mathrm{SB}_{\mathrm{i}}$ & Baik \\
$\mathrm{C}$ & $\bar{X}_{\mathrm{i}}-0,60 \mathrm{SB}_{\mathrm{i}}<\mathrm{X} \leq \overline{\bar{X}}_{\mathrm{i}}+0,60 \mathrm{SB}_{\mathrm{i}}$ & Cukup \\
$\mathrm{D}$ & $\overline{\bar{X}}_{\mathrm{i}}-1,80 \mathrm{SB}_{\mathrm{i}}<\mathrm{X} \leq \overline{\bar{X}}_{\mathrm{i}}+0,60 \mathrm{SB}_{\mathrm{i}}$ & Kurang \\
$\mathrm{E}$ & $\mathrm{X} \leq \overline{\mathrm{X}}_{\mathrm{i}}-1,80 \mathrm{SB}_{\mathrm{i}}$ & Sangat \\
\hline
\end{tabular}




\section{Analisis Hasil Pretest dan Posttest}

Sedangkan untuk mengetahui efektivitas produk berupa tingkat pemahaman materi yang telah diajarkan diwujudkan dalam skor tes hasil belajar setelah menggunakan produk yang dikembangkan. Data pretest dan posttest hasil belajar dianalisis dengan membandingkan skor pretest dan skor posttest. Peningkatan yang terjadi sebelum kegiatan pembelajaran dengan menggunakan buku teks tematik tema permainan dan sesudah pembelajaran dengan menggunakan buku teks tematik tema permainan diperhitungkan dengan rumus (n-gain) yang ditentukan berdasarkan rata-rata gain skor yang dinormalisasi (g) yaitu perbandingan dari skor gain. Skor gain yaitu skor gain yang diperoleh siswa pretest dan Posttest sedangkan skor gain maksimum yaitu skor gain tertinggi yang diperoleh siswa. Rata-rata gain yang dinormalisasi (nGain) (Hake, 1998, p.2) dinyatakan oleh persamaan sebagai berikut:

$$
\mathrm{g}=\frac{\text { Spost }- \text { Spre }}{\text { Smaks-Spre }}
$$

Keterangan :

$\begin{array}{ll}\text { S-Post } & \text { : Skor Posttest } \\ \text { S-Pre } & : \text { Skor Pretest } \\ \text { S-Maks } & : \text { Skor Maksimal }\end{array}$

Nilai ini kemudian diinterpretasikan ke dalam Tabel 3 klasifikasi Nilai Gain (Hake, 1998, p.3) berikut:

Tabel 3. Klasifikasi Nilai Gain

\begin{tabular}{cc}
\hline Nilai $(\mathbf{g})$ & Klasifikasi \\
\hline$(\mathrm{N}-$ gain $) \geq 0,7$ & Tinggi \\
$0,7>(\mathrm{N}-$ gain $) \geq 0,3$ & Sedang \\
$(\mathrm{N}-$ gain $)<0,3$ & Rendah \\
\hline
\end{tabular}

\section{Hasil Penelitian dan Pembahasan}

\section{Analisis Data Hasil Validasi Ahli Materi}

Dalam analisis data hasil validasi produk ahli materi ini terdapat dua aspek yang menjadi penilaian ahli materi yaitu aspek kelayakan isi,dan aspek penyajian. Berikut diagram rangkuman hasil penilaian ahli materi:

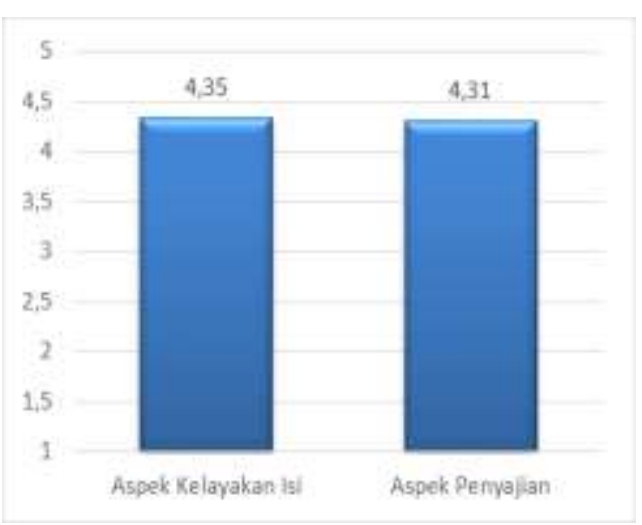

Gambar 1. Diagram Penilaian Ahli Materi

Berdasarkan tabel dan diagram penilaian ahli materi terhadap produk yang dikembangkan diketahui bahwa penilaian ahli materi terhadap aspek kelayakan isi mendapat nilai rata-rata sebesar 4,35, rata-rata tersebut termasuk dalam kategori sangat baik, sehingga dapat dikatakan bahwa aspek kelayakan isi dalam buku teks tematik tema permainan yang dikembangkan sudah memenuhi syarat kelayakan isi yang baik sebagai sebuah bahan ajar. Penilaian ahli materi terhadap aspek penyajian mendapatkan nilai 4,31, rata-rata tersebut termasuk dalam kategori sangat baik, sehingga dapat dikatakan bahwa aspek penyajian dalam buku teks tematik tema permainan yang dikembangkan sudah memenuhi syarat penyajian yang baik sebagai sebuah bahan ajar.

\section{Analisis Data Hasil Validasi Ahli Media}

Dalam analisis data hasil validasi produk ahli media ini terdapat dua aspek yang menjadi penilaian ahli media yaitu aspek kebahasaan, dan aspek kegrafikan. Berikut diagram rangkuman hasil penilaian ahli media:

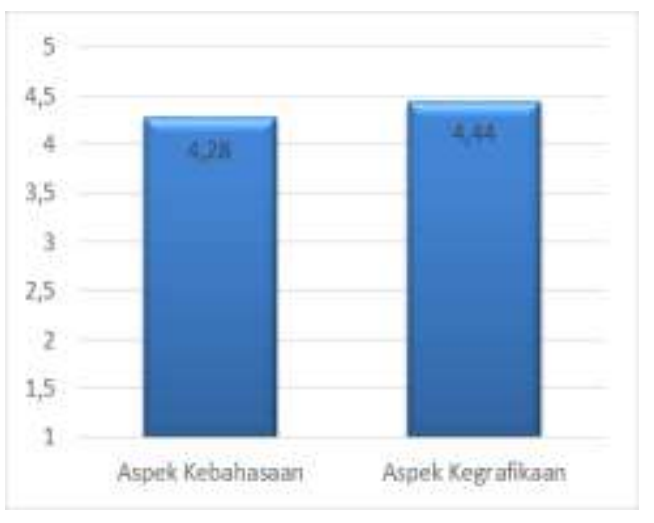

Gambar 2. Diagram Penilaian Ahli Media

Berdasarkan tabel dan diagram penilaian ahli media terhadap produk yang dikembangkan diketahui bahwa penilaian ahli media 
terhadap aspek kebahasaan mendapat nilai ratarata sebesar 4,28, rata-rata tersebut termasuk dalam kategori sangat baik, sehingga dapat dikatakan bahwa aspek kebahasaan dalam buku teks tematik tema permainan yang dikembangkan sudah memenuhi syarat kebahasaan yang baik sebagai sebuah bahan ajar. Penilaian ahli media terhadap aspek kegrafikan mendapatkan nilai 4,44 , rata-rata tersebut termasuk dalam kategori sangat baik, sehingga dapat dikatakan bahwa aspek kegrafikan dalam buku teks tematik tema permainan yang dikembangkan sudah memenuhi syarat kegrafikan yang baik sebagai sebuah bahan ajar.

\section{Hasil Penilaian Produk oleh Guru}

Dalam analisis data penilaian produk oleh guru atau praktisi ini terdapat empat aspek yang menjadi penilaian ahli media yaitu aspek kelayakan isi, aspek penyajian, aspek kebahasaan dan aspek kegrafikan. Berikut diagram rangkuman hasil penilaian ahli media.

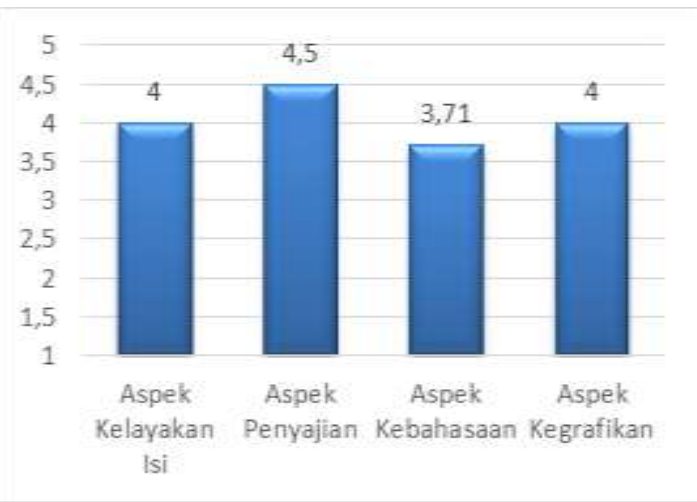

Gambar 3. Diagram Penilaian Guru atau Praktisi

Berdasarkan tabel dan diagram penilaian guru terhadap produk yang dikembangkan diketahui bahwa penilaian guru terhadap aspek kelayakan isi mendapat nilai rata-rata sebesar 4, rata-rata tersebut termasuk dalam kategori baik, sehingga dapat dikatakan bahwa aspek kelayakan isi dalam buku teks tematik tema permainan yang dikembangkan sudah memenuhi syarat kelayakan isi yang baik sebagai sebuah bahan ajar. Penilaian guru terhadap aspek penyajian mendapatkan nilai 4,56, rata-rata tersebut termasuk dalam kategori sangat baik, sehingga dapat dikatakan bahwa aspek penyajian dalam buku teks tematik tema permainan yang dikembangkan sudah memenuhi syarat penyajian yang baik sebagai sebuah bahan ajar.
Berdasarkan tabel dan diagram penilaian guru terhadap produk yang dikembangkan diketahui bahwa penilaian guru terhadap aspek kebahasaan mendapat nilai rata-rata sebesar 3,71, rata-rata tersebut termasuk dalam kategori baik, sehingga dapat dikatakan bahwa aspek kebahasaan dalam buku teks tematik tema permainan yang dikembangkan sudah memenuhi syarat kebahasaan yang baik sebagai sebuah bahan ajar. Penilaian guru terhadap aspek kegrafikan mendapatkan nilai 4 , rata-rata tersebut termasuk dalam kategori baik, sehingga dapat dikatakan bahwa aspek kegrafikan dalam buku teks tematik tema permainan yang dikembangkan sudah memenuhi syarat kegrafikan yang baik sebagai sebuah bahan ajar.

\section{Analisis Data Hasil Belajar Uji Coba Terbatas}

Uji coba terbatas dilakukan pada siswa kelas tiga Sekolah Dasar Negeri Tridadi sebanyak 9 orang siswa. Pemilihan subjek uji coba dilakukan dengan membagi siswa ke dalam kategori prestasi tinggi, sedang, dan rendah. Masing-masing kategori diwakili oleh 3 orang siswa. Tujuan uji coba terbatas adalah untuk mengumpulkan informasi yang dapat digunakan sebagai bahan untuk merevisi atau memperbaiki produk untuk digunakan dalam uji coba lapangan serta melihat efektivitas produk dalam pembelajaran dilihat dari peningkatan skor pretest dan posttest dalam skala yang lebih kecil. Informasi yang diperoleh dari uji coba terbatas ini adalah data respons siswa terhadap buku teks tematik tema permainan yang dikembangkan serta nilai skor pretest dan posttest. Berikut diagram uji coba terbatas:

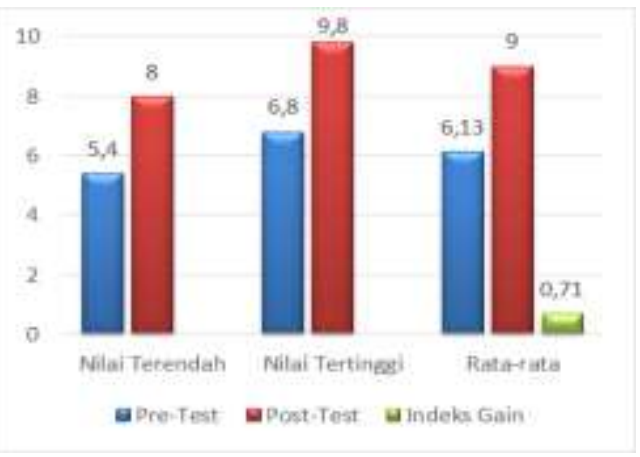

Gambar 4. Diagram Hasil Pretest Posttest dan Rata-Rata Indeks Uji Coba Terbatas

Setelah dilakukan analisis data menggunakan teknik Gain Score, maka diperoleh indeks gain dari masing-masing siswa dan kriteria peningkatan efektivitas siswa dari skor pretest dan skor posttest siswa. Dari data di atas 
terdapat peningkatan skor hasil belajar siswa antara skor pretest dan skor posttest. Untuk rerata indeks gain seluruh siswa didapatkan skor sebesar 0,71, angka tersebut berdasarkan tabel klasifikasi nilai gain (Hake, 1998, p.3) termasuk dalam kriteria tinggi. Sehingga dalam uji coba terbatas ini efektivitas produk yang dikembangkan dalam proses pembelajaran berdasarkan hasil skor pretest dan posttest termasuk dalam kriteria efektivitas yang "TINGGI".

\section{Analisis Respon Siswa Uji Coba Terbatas}

Data hasil respons siswa terhadap produk ditinjau dari aspek materi, pembelajaran, bahasa, dan grafika. Data yang diperoleh kemudian dihitung persentase siswa yang memilih pilihan "ya" dan "tidak". Jumlah persentase pilihan "ya" kemudian dilihat, jika jumlah persentase sama dengan atau melebihi 50\% maka respons siswa terhadap buku teks tematik tema permainan yang dikembangkan dinyatakan "baik" sedangkan jika rata-rata persentase siswa yang memilih "tidak" melebihi $50 \%$ maka respons siswa terhadap buku teks tematik tema permainan dinyatakan "tidak baik". Berikut diagram rangkuman respons siswa dalam uji coba terbatas.

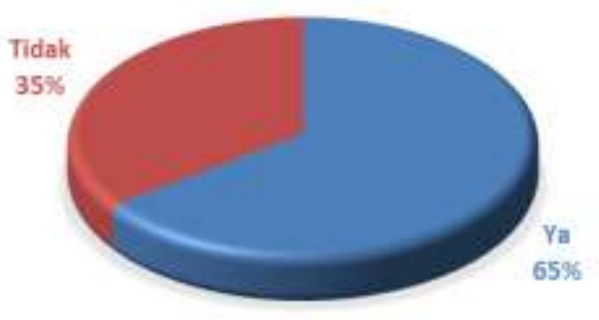

Gambar 5. Diagram Respons Siswa Uji Coba Terbatas

Berdasarkan diagram di atas diketahui bahwa respons siswa pada uji coba terbatas terhadap produk yang dikembangkan sebanyak $65 \%$ siswa dalam uji coba terbatas memberikan respons yang baik terhadap produk, sedangkan 35\% siswa memberikan respons yang tidak baik terhadap produk yang dikembangkan.

\section{Analisis Data Hasil Belajar Uji Coba Diperluas}

Pretest dan posttest dilakukan untuk menguji kemampuan kognitif Siwa. Pretest di- berikan diawal atau sebelum pembelajaran dengan produk pengembangan buku teks tematik tema permainan dilakukan untuk mengetahui kemampuan awal kognitif siswa, sedangkan posttest diberikan diakhir atau setelah siswa selesai melakukan pembelajaran dengan produk yang dikembangkan yaitu buku teks tematik tema permainan. Berikut diagram analisis hasil pretest dan posttest siswa uji coba diperluas.

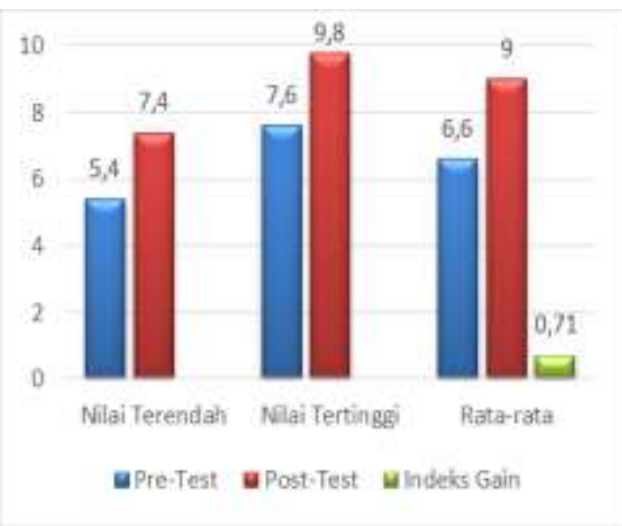

Gambar 6. Diagram Hasil Pretest Posttest dan Rata-Rata Indeks Gain Uji Coba Diperluas

Berdasarkan tabel di atas diketahui bahwa terjadi peningkatan hasil belajar setelah mengalami proses pembelajaran. Perubahan skor hasil belajar ini dihitung dengan teknik standar gain (gain standar), yaitu kenaikan skor diperoleh dengan cara skor akhir (posttest) dikurangi skor awal (pretest) kemudian dibagi dengan hasil pengurangan antara skor maksimum dengan skor awal (pretest).

Untuk menentukan kategori efektivitas produk pengembangan buku teks tematik tema permainan ini, berdasarkan hasil pretest dan posttest siswa dilihat dari jumlah rata-rata indeks skor gain seluruh siswa kelas 3 yaitu sebesar 0,71. Berdasarkan tabel klasifikasi nilai gain maka efektivitas dari produk pengembangan ini termasuk dalam klasifikasi kategori "TINGGI".

\section{Analisis Respons Siswa Uji Coba Diperluas}

Uji coba diperluas atau uji coba lapangan ini dilakukan kepada seluruh siswa kelas 3 SDN Tridadi yang berjumlah 28 orang siswa. Data respons siswa ini dimaksudkan untuk mengetahui respons atau tanggapan siswa terhadap buku teks tematik tema permainan. Lembar angket respons siswa ini diberikan setelah siswa selesai melakukan pembelajaran dengan menggunakan buku teks tematik tema permainan. 


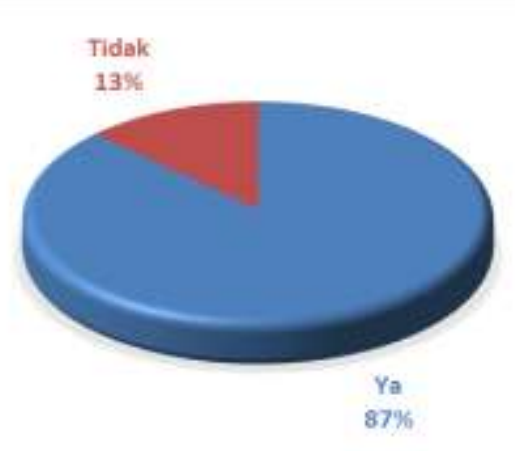

Gambar 7. Diagram Respons Siswa Uji Coba Terbatas

Berdasarkan tabel di atas diketahui bahwa respons siswa terhadap produk yang dikembangkan sebesar $87 \%$ siswa memberikan respons yang baik terhadap produk yang dikembangkan, sedangkan sebesar $13 \%$ siswa memberikan respons yang tidak baik terhadap produk yang dikembangkan. Dari data di atas dapat disimpulkan bahwa respons siswa kelas III terhadap buku teks tematik tema permainan yang dikembangkan memberikan respons yang baik sehingga produk yang dikembangkan ini dapat membantu siswa dalam proses pembelajaran tematik di Sekolah Dasar kelas III khususnya SDN Tridadi.

Revisi Produk

Revisi dilakukan berdasarkan saran dari ahli materi/media, guru, dan respons siswa. Revisi dilakukan sebanyak tiga kali, revisi pertama dilakukan setelah mendapatkan saran dai ahli materi dan ahli media, revisi kedua dilakukan setelah diperoleh temuan pada uji coba terbatas, selanjutnya revisi ketiga dilakukan setelah diperoleh temuan pada uji coba lapangan serta penilaian, saran dan komentar dari guru. Tahap revisi tersebut dirangkum sebagai berikut: perbaikan kesalahan pengetikan pada kalimat, perbaikan pada penggunaan Ejaan Yang Disempurnakan (EYD), gambar-gambar yang terdapat dalam buku perlu disesuaikan lagi dengan deskripsi materi, penambahan muatan "materi" permainan pada topik yang belum secara eksplisit disajikan, perlu konsistensi penyebutan siswa/kalian/pendidik pada tujuan pembelajaran, perlu dipertegas penguatan konsep untuk siswa, gambar-gambar yang terdapat pada buku dibuat lebih proporsional dan harus disertai keterangan gambar, beberapa penggunaan istilah ada yang harus diganti karena harus disesuaikan dengan usia siswa kelas 3, perbaikan pada cover atau sampul buku yang lebih menarik dan disesuaikan dengan tema permainan serta ditambah logo kurikulum KTSP 2006, perbaikan pada tata letak gambar, materi yang disajikan harus dipastikan kebenarannya agar tidak terjadi salah konsep atau miskonsepsi yang berakibat pada pemahaman materi siswa.

\section{Kajian Produk Akhir}

Penelitian pengembangan ini bertujuan untuk mengembangkan bahan ajar berupa buku teks tematik tema permainan berdasarkan Standar Isi Kurikulum KTSP. Terdapat tiga urutan pelaksanaan penelitian yang dilakukan dalam pengembangan produk buku teks tematik tema permainan yaitu: (1) validasi ahli materi dan validasi ahli media (2) uji coba terbatas (3) uji coba lapangan. Hasil akhir produk pengembangan ini adalah buku teks tematik tema permainan untuk kelas 3 Sekolah Dasar. Setelah melalui urutan pelaksanaan penelitian di atas maka hasil dari penelitian pengembang-an ini sudah dapat digunakan sebagai salah satu bahan ajar dalam proses pembelajaran tematik di kelas 3.

Buku teks pelajaran yang berkualitas harus memperhatikan komponen-komponen yang ditetapkan oleh Badan Standar Nasional Pendidikan (BSNP), yaitu aspek kelayakan isi, penyajian, aspek bahasa, aspek kegrafisan. Berikut kajian produk akhir dari pengembangan buku teks tematik tema permainan dari masing-masing aspek.

Aspek Kelayakan Isi

Materi pada buku teks tematik tema permainan ini merupakan perpaduan dari berbagai mata pelajaran antara lain: IPA, IPS, Matematika, Bahasa Indonesia, dan Pendidikan Kewarganegaraan (PKN). Dari berbagai disiplin ilmu atau mata pelajaran tersebut kemudian dipadukan dengan sebuah tema yang telah ditetapkan yaitu tema permainan, ini berarti setiap materi dari mata pelajaran tersebut dikaitkan dengan tema permainan.

Menurut penilaian ahli materi aspek kelayakan isi dalam buku teks tematik tema permainan ini termasuk dalam kategori "sangat baik". Hal ini berarti menurut penilaian ahli materi, aspek kelayakan isi yang disajikan dalam buku ini sudah memenuhi syarat untuk dilakukan dalam proses pembelajaran. Penilaian lain juga diberikan oleh guru atau praktisi selaku pengguna produk yang dikembangkan dalam proses pembelajaran di kelas. Menurut penilaian guru aspek kelayakan isi dalam buku 
teks tematik tema permainan yang dikembangkan ini termasuk dalam kategori "baik". Hal ini berarti guru merasa bahwa aspek kelayakan isi yang disajikan dalam buku teks tematik tema permainan yang digunakan guru dalam proses pembelajaran sudah mencakup semua materi dalam rangka pencapaian indikator yang diharapkan.

Respons siswa dalam penelitian ini juga menunjukkan tanggapan yang "baik" dari aspek materi dalam buku teks tematik tema permainan hal ini ditunjukkan dari rata-rata aspek materi pada uji coba terbatas dan uji coba diperluas sebesar $72 \%$ siswa menyatakan respons yang baik terhadap aspek materi. Data hasil rata-rata skor gain pretest dan posttest siswa juga menunjukkan klasifikasi "tinggi", ini berarti siswa sudah mampu menerima materi pelajaran yang diberikan dengan baik.

Aspek Penyajian

Penilaian terhadap buku teks tematik tema permainan ini dari aspek penyajian menunjukkan hasil yang positif. Hasil penilaian ahli materi dari aspek penyajian dalam buku teks tematik tema permainan ini termasuk dalam kategori "sangat baik". Penilaian dari guru terhadap buku teks tematik tema permainan ini dari aspek penyajian termasuk dalam kategori "sangat baik".

Aspek penyajian juga merupakan bahan penilaian untuk sebuah bahan ajar yang baik. Sebuah bahan ajar harus dapat membuat pembelajaran menjadi menyenangkan dan memotivasi siswa dalam belajar. Berdasarkan penilaian ahli materi dalam aspek penyajian, buku teks tematik tema permainan ini termasuk dalam kategori "sangat baik". Hal ini menunjukkan bahwa aspek penyajian dengan menggunakan buku teks tematik tema permainan ini sudah memenuhi syarat dalam penyajian buku teks yang baik. Penilaian guru sebagai pengguna buku dalam proses pembelajaran dikelas memberikan penilaian untuk aspek penyajian ini termasuk dalam kategori "sangat baik". Hal tersebut mengindikasikan bahwa guru selama proses pembelajaran dengan menggunakan buku teks tematik tema permainan ini merasa aspek penyajian yang disajikan dalam buku ini sudah baik.

Respons siswa dalam aspek penyajian pembelajaran buku teks tematik tema permainan menunjukkan respons positif atau "baik", hal ini ditunjukkan dari rata-rata respons siswa pada uji coba terbatas dan diperluas menunjukkan sebesar 81,55\% siswa menyatakan respons positif pada aspek pembelajaran. Hal ini tentu dapat memotivasi siswa dalam mengikuti proses pembelajaran. Kualitas aspek materi buku pelajaran juga menjadi penting untuk diperhatikan karena menurut Harris \& Sipay (1984), tingkat kesulitan isi/materi buku merupakan salah satu faktor lain yang dapat mempengaruhi minat baca siswa disamping faktor ilustrasi buku dan bacaan komik.

\section{Aspek Kebahasaan}

Aspek kebahasaan juga merupakan bahan penilaian dalam produk bahan ajar buku yang dikembangkan, karena bahasa merupakan salah satu bagian penting dalam penyampaian materi kepada siswa. Penilaian aspek kebahasaan ini dinilai oleh ahli media. Penilaian oleh ahli media terhadap buku teks tematik tema permainan ini dari aspek kebahasaan termasuk dalam kategori "sangat baik". Hal menunjukkan bahwa penggunaan bahasa dalam buku teks tematik tema permainan ini sudah sesuai dengan karakteristik siswa dan dapat dipahami dengan baik oleh siswa. Hal tersebut juga sesuai dengan penilaian dari guru terhadap buku teks tematik tema permainan pada aspek kebahasaan yang termasuk dalam kategori 'baik".

Respons siswa terhadap aspek kebahasaan dalam uji coba terbatas dan uji coba diperluas menunjukkan rata-rata sebesar $73,40 \%$ siswa menyatakan respons atau tanggapan yang positif terhadap buku teks tematik tema permainan dari aspek kebahasaan. Hal ini menunjukkan bahwa sebagian besar siswa dapat memahami bahasa dan istilah yang terdapat di dalam buku teks tematik tema permainan ini dengan baik.

\section{Aspek Kegrafikan}

Aspek kegrafikan merupakan aspek penting dalam sebuah bahan ajar terutama untuk kelas rendah. Aspek kegrafikan yang baik dalam sebuah bahan ajar dapat memotivasi atau menarik minat siswa untuk membaca dan mempelajari sebuah bahan ajar. Penilaian aspek kegrafikan dalam buku teks tematik tema permainan ini menurut ahli media termasuk dalam kategori "sangat baik", dan penilaian aspek kegrafikan oleh guru termasuk dalam kategori "baik". Rata-rata respons siswa terhadap buku teks tematik tema permainan dari aspek kegrafikan dalam uji coba terbatas dan uji coba lapangan sebesar 87,05\% siswa menyatakan respons yang positif terhadap buku teks tematik 
tema permainan ini dari aspek kegrafikan. Ini berarti gambar-gambar, layout, sampul yang terdapat di dalam buku teks tematik tema permainan dianggap menarik bagi siswa dan membuat siswa tertarik untuk membaca dan mempelajari materi yang disajikan dalam baku teks tematik tema permainan ini. Kualitas aspek grafika buku pelajaran penting untuk diperhatikan karena menurut Huck dan Hicman (1987, p.49) " although reading preferences are influenced by age, sex, and many other factors, Children often make specific choices based on the book itself its length, format, cover, or the appeal of a sampel paragraph. Sering kali siswa memilih buku pelajaran didasarkan pada model buku seperti panjangnya, formatnya, model sampulnya, atau paragraf pengantar, demikian juga ilustrasi, warna, format, panjang pendeknya, dan model cetakan adalah tampilan buku yang berpengaruh terhadap pilihan siswa.

Temuan Pada Uji Coba Lapangan

Uji coba lapangan dilakukan untuk mengetahui efektivitas penggunaan buku yang dikembangkan pada proses pembelajaran tematik dikelas. Dalam uji coba lapangan ini akan dilihat kriteria peningkatan hasil belajar siswa dengan teknik gain score. Setelah dilakukan proses pembelajaran didapatkan beberapa temuan diantaranya yaitu adanya peningkatan hasil belajar siswa ke dalam klasifikasi "tinggi. Hal ini menunjukkan bahwa buku teks tematik tema permainan yang dikembangkan memiliki kriteria efektivitas tinggi dalam meningkatkan hasil belajar siswa.

Berdasarkan temuan tersebut dapat dikatakan bahwa pembelajaran tematik dengan menggunakan buku teks tematik tema permainan memberikan pengaruh yang baik terhadap pencapaian hasil belajar siswa. Dengan demikian berdasarkan kajian akhir tersebut dapat dikatakan bahwa buku teks tematik tema permainan hasil pengembangan ini merupakan produk yang layak digunakan sebagai salah satu bahan ajar dalam proses pembelajaran tematik dikelas 3 Sekolah Dasar.

Beberapa keunggulan buku teks tematik tema permainan ini antara lain praktis karena siswa dan guru dalam melaksanakan proses pembelajaran tematik dikelas cukup hanya dengan membawa satu buku ini saja karena di dalam buku teks tematik ini sudah mencakup materi pelajaran dari mata pelajaran IPA, IPS, Matematika, Bahasa Indonesia, dan PKN yang dikaitkan dengan tema permainan. Selain ke- unggulan tersebut, produk pengembangan buku teks tematik ini memiliki kelemahan yaitu dalam buku teks tematik ini hanya terdapat satu tema saja. Selain itu kelemahan juga terdapat pada keterkaitan materi dengan kehidupan sehari-hari siswa. Hal tersebut berdasarkan respons siswa yang menyatakan bahwa materi tidak terkait dengan kehidupan sehari-hari siswa. Hal ini mungkin disebabkan oleh jenis permainan yang disajikan dalam buku tidak terkait langsung dengan kehidupan sehari-hari siswa.

\section{Simpulan dan Saran}

Simpulan

Berdasarkan hasil penelitian dan analisis data maka diperoleh kesimpulan dalam penelitian pengembangan ini sebagai berikut: produk hasil penelitian dan pengembangan ini berupa buku teks tematik tema permainan berdasarkan hasil penelitian dan penilaian ahli materi, ahli media, dan guru pada aspek kelayakan isi, aspek penyajian, aspek kebahasaan, dan aspek kegrafikan dinyatakan layak sebagai salah satu bahan ajar dalam proses pembelajaran tematik di sekolah dasar kelas III, respons atau tanggapan siswa terhadap produk yang dikembangkan berupa buku teks tematik tema permainan, berdasarkan data hasil penelitian menunjukkan respons atau tanggapan yang termasuk dalam kategori baik, buku teks tematik tema permainan yang dikembangkan efektif dalam peningkatan hasil belajar siswa berdasarkan skor hasil pretest dan posttest. Hal ini ditunjukkan dengan rerata gain score siswa kelas III pada uji coba terbatas dan uji coba diperluas sebesar 0,71 . Rerata tersebut termasuk dalam kategori tinggi.

\section{Saran Pemanfaatan}

\section{Saran Pemanfaatan Bagi Guru}

Adapun saran dalam pemanfaatan produk pengembangan buku teks tematik tema permainan ini bagi guru adalah dalam melakukan kegiatan yang ada di dalam buku teks tematik ini guru hendaknya memberikan langkah-langkah yang jelas dan tetap memberikan pengawasan kepada siswa agar makna dan tujuan kegiatan dapat dipahami dengan baik oleh siswa.

\section{Saran Pemanfaatan bagi Siswa}

Saran pemanfaatan bagi siswa adalah ketika melakukan proses pembelajaran dengan 
menggunakan buku teks tematik tema permainan ini siswa tidak perlu lagi atau siswa tidak diharuskan membawa buku mata pelajaran lain, karena hanya akan menambah beban barang bawaan siswa sebab materi dalam buku ini sudah mencakup mata pelajaran IPA, IPS, Matematika, Bahasa Indonesia, dan PKN.

\section{Pengembangan Produk Lebih Lanjut}

Apabila akan dilakukan penelitian pengembangan tentang buku teks tematik yang lain maka sebaiknya dilakukan pengembangan dengan tema yang berbeda serta jika memungkinkan dapat ditambahkan dengan mata pelajaran lain sehingga buku teks tematik akan semakin bervariasi. Untuk tahap desiminasi atau penyebaran apabila akan dilakukan pengembangan lebih lanjut dapat dilakukan desiminasi atau penyebaran ke sekolah lain. Selain itu apabila akan dilakukan pengembangan buku teks tematik yang lain disarankan agar sedapat mungkin Standar Kompetensi dan Kompetensi Dasar yang dipilih serta soal-soal evaluasi benar-benar dikaitkan secara kontekstual dengan tema yang akan dipilih sebagai tema buku teks tematik.

\section{Daftar Pustaka}

Borg, W.R., Gall, M.D., \& Gall, J.P. (1983). Educational research. an introduction. New York: Longman.

Hake, R.R. (1998). Interactive engagement methods in introductory mechanics courses. Departement of Physics, Indiana University, Bloomingtoon.

Harris, A,J \& Sipay, E.R. (1980). How to increase reading ability. New York: Longman.

Huck, C.S., Hepler. S., \& Hicman, J. (1987). Children`s literatur in the elementary school. New York: Holt Rinehart Ana Winston Inc.

Indrawati. (2009). Model pembelajaran terpadu di sekolah dasar. Jakarta: Pusat Pengembangan dan Pemberdayaan Pendidik dan Tenaga Kependidikan Ilmu Pengetahuan Alam.

Miller, Christoper. (2008). Games: purpose and potential in education. New York: Springer Science Business Media.

Peters, Tim; Schubeck, Kathy; Hopkins, Karen.(1995). A thematic approach: theory and practice at the aleknagik school. United States: Phi Delta Kappa. Jurnal diakses dari Proquest

Rusman. (2012). Model-model pembelajaran: mengembangkan profesionalisme guru. Jakarta: Rajawali Pers.

Sitepu, B.P. (2012). Penulisan buku teks pelajaran, Bandung: Rema Rosdakarya Offset.

Sukardjo, (2010). Evaluasi pembelajaran. Buku pegangan kuliah: PPS UNY.

Thiagarajan, S., Semmel, D.S., and Semmel, M.I. (1974). Instructional development for training teachers of exceptional childreen. Leadership training institute/special education, Minnesota: University of Minnesota, Minneapolis.

UNESCO. (2005). A comprehensive strategy for textbook and learning materials. France: UNESCO.

Quest, Hall., Lawrence, Alfred. (2006). The textbook: how to uses it and jugde it. New York: The Mc Millan Company. 